КОМПЕТЕНТНОСТІ 3 МИСТЕЦТВА ХУДОЖНЬОГО ТКАЦТВА ЯК СКЛАДНИК ПРОФЕСІЙНОЇ КОМПЕТЕНТНОСТІ МАЙБУТНЬОГО ФАХІВЦЯ ДЕКОРАТИВНО-ПРИКЛАДНОГО МИСТЕЦТВА

\title{
THE ESSENCE OF THE CONCEPT OF COMPETENCIES IN THE ART OF ARTISTIC WEAVING OF THE FUTURE SPECIALIST IN ARTS AND CRAFTS IN ACCORDANCE WITH STATE STANDARDS OF UKRAINE
}

УДК 378.147:745/749

DOI https://doi.org/10.32843/26636085/2021/31-1.20

\section{Липовецька Є.ю.}

аспірант кафедри теорії та методики просресійної освіти

Ніжинського державного університету імені Миколи Гоголя,

викладач кафредри мистецтв

Ніжинського коледжу культури і

мистецтв імені Марії Заньковецької
В освітньому просторі спостерігається помітне зростання педагогічного інтересу до відродження традиційних художніх народних промислів із художнього ткацтва, килимарства, вишивки, мереживоплетіння. Існують і педагогічно процвітають численні центри вивчення традиційних народних ремесел (клуби, студії, гуртки, школи, коледжі, інститути), у яких вивчаються і реалізуються традиції народних мистецтв.

Учені, художники текстильних промислів, педагоги не перестають звертатися до традицій, продовжують дослідження побуту народів світу, розглядаючи особливості ткацьких технологій і знарядь праці, вивчення і розширровку тканого орнаменту, його значення і ролі в системі національноі культури. Для підвищення візуальної бібліотеки і розвитку почуття декоративності часто проводяться майстер-класи, конкурси, семінари, на яких майстри діляться своїм унікальним досвідом. Особливе місце у розкритті художніх сторін у традиційному декоративному мистецтві займають фестивалі та виставки, оскільки побудова експозицій забезпечує можливість учням побачити дивовижні вироби, виконані в техніці художнього ткацтва, килимарства, а також вишивки.

Декоративна діяльність, а саме вивчення художнього текстилю, розглянута у дослідженні, дає широкі можливості для розкриття індивідуальності. Заснована на багатовіковому народному досвіді, вона розвиває творчі здібності, духовно збагачує особистість, несе в собі знання і вміння багатьох поколінь. У прочесі художнього ткацтва формується інтелектуальний потенціал, розвивається психіка, творча активність, ініціатива, виховуються посидючість, працьовитість. Проте нині ссрормовано протиріччя між вивченістю питань формування професійних компетентностей студентів у педагогічній теорії і практиці та їх недостатньою розробленістю 3 підготовки фрахівців декоративно-прикладного мистецтва.

У статті розглянуто компетентності 3 мистецтва художнього ткацтва як складник просресійної компетентності майбутнього фрахівия декоративно-прикладного мистецтва.

Ключові слова: художнє ткацтво, декоративно-прикладне мистецтво, срахова компетентність, компетентності з мистецтва художнього ткацтва, педагогіка, художня освіта, професійна освіта.

In the educational space there is a marked increase in pedagogical interest in the revival of traditional folk crafts in artistic weaving, carpet weaving, embroidery, lace weaving. There are and pedagogically prosperous numerous centers for the study of traditional folk crafts, such as clubs, studios and clubs, schools, colleges and institutes, which study and implement the traditions of folk arts.

Scientists, artists of textile crafts, teachers do not stop turning to traditions, continue to study the life of the peoples of the world, considering the features of weaving technologies and tools, continue to study and decipher the woven ornament, its meaning and role in national culture. To improve the visual library and develop a sense of decorativeness, master classes, competitions, seminars are often held, at which masters share their unique experience. Festivals and exhibitions occupy a special place in the disclosure of artistic aspects in traditional decorative art, as the construction of exhibitions provides an opportunity for students to see amazing products made in the technique of artistic weaving, carpet weaving and embroidery. Decorative activity, namely the study of artistic textiles, considered in the study, provides ample opportunities for the disclosure of individuality. Based on centuries of folk experience, it develops creative abilities, spiritually enriches the personality, carries the knowledge and skills of many generations. In the process of artistic weaving the psyche develops, intellectual potential is formed, creative activity, initiative develop, perseverance, diligence and much more are brought up. However, currently there is a contradiction between the study of the formation of professional competencies of students in pedagogical theory and practice and their lack of development in the training of arts and crafts.

The article considers the competencies in the art of artistic weaving as a component of the professional competence of the future specialist in a decorative arts, semantic, artistic, technological aspects of hand weaving are considered.

Key words: artistic weaving, decorative and applied art, professional competence, competence in the art of artistic weaving, pedagogy, art education, professional education.
Постановка проблеми в загальному вигляді. В сучасних умовах системи мистецької освіти поширене збереження і розвиток народних традицій в області художнього ткацтва. Нині основна відмінність методичних основ навчання художньої обробки текстильних матеріалів (на прикладі художнього ткацтва) полягає у тому, що, на відміну від системи навчання, яка панувала ще якихось 20 років тому, в художній практиці студентів використовується проектування, застосовуються комп'ютерні технології, подача візуалізованих матеріалів здійснюється 3 інтернет-ресурсів [3; 5]. При всій схожості навчання на рівні оволодіння техніко-технологічними основами в області 
художнього ткацтва має місце відмінність в організації проектного виконання робіт і переведення їх у матеріал. Закономірності навчання за типом творчості в декоративно-прикладному мистецтві (повтор, варіація, імпровізація) зберігаються в рамках народної культури, творчості, самобутності, а також у зверненнях до позицій арт-індустрії.

Для вдосконалення художньої майстерності у студентів необхідно використовувати традиційні навчальні матеріали, починаючи від створення орнаментальної композиції до створення проекту в матеріалі. Загалом така методика навчання спрямована на включення студентів у простір стилізації як прийому художньої організації орнаментики на поверхні текстильного об'єкта.

У системі профресійної мистецької освіти навчання відбувається шляхом вивчення технологічних прийомів 3 використанням технічних замальовок, що здебільшого співвідноситься з етапами роботи народних майстрів і є необхідним для розвитку насамперед ручної вмілості у студентів.

Методичні основи навчання художньої обробки текстильних матеріалів у рамках художнього проектування в техніці художнього ткацтва спрямовані на гармонійну взаємодію традицій і сучасної освіти. Навчання необхідно проводити на об'єктах, в умовах вивчення і використання матеріалів народних художніх текстильних промислів. Методика полягає не лише у збереженні технікотехнологічних аспектів народного мистецтва, а й у підготовці студентів до дотримання технологічних і образних основ декоративного мистецтва. Необхідно мати на увазі, що нині прикладний характер мистецтва здебільшого перегукується 3 ідеями наростання естетики і ослаблення фрункціональних закономірностей, що є загальним художнім процесом, який впливає на естетичну затребуваність творів цього виду мистецтва.

Нині сорормувалося протиріччя між вимогами сучасного суспільства до рівня майстерності майбутніх фрахівців декоративно-прикладного мистецтва і відсутністю науково-обґрунтованої системи поетапного формування компетентностей із художнього ткацтва різних рівнів [1, с. 283].

Аналіз останніх досліджень і публікацій. Загальна френоменологія професійної компетентності вчителя знайшла відображення у дослідженнях Г. Балла, О. Бондаревської, Н. Гузій, І. Зимньої, Н. Кузьміної, А. Маркової, В. Маслова, О. Пометуна, О. Савченко, О. Хуторського. Дослідження у сорері педагогіки мистецтва здійснювали О. Гайдамака, О. Кабкова, Л. Масол, Н. Миропольська, М. Михаськова, О. Олексюк, Г. Падалка, О. Рудницька, М. Семко, О. Щолокова.

Вивченням методики фрормування певних компонентів фрахової компетентності вчителя мистецьких дисциплін займалися І. Зязюн, М. Лещенко, Л. Масол, Г. Падалка, О. Ростовський, О. Руд- ницька, О. Щолокова. Мистецьку компетентність як необхідну умову професійного виконання фахових обов'язків вчителя образотворчого мистецтва розглядали О. Кайдановська, С. Коновець, І. Мужикова, О. Плотницька [2, с. 71-79].

Виділення не вирішених раніше частин загальної проблеми. У дослідженнях переважає аналіз окремих компонентів професійного становлення студентів, однак питання освоєння компетентностей із художнього ткацтва як чітко сорормованої системи, яка утворює комплекс навчально-творчих завдань зростаючої складності, не отримали належного висвітлення.

Мета статті - розкрити сутність поняття «компетентностей із мистецтва художнього ткацтва» як складника професійної компетентності майбутнього фрахівця декоративно-прикладного мистецтва.

Виклад основного матеріалу. Виявлена актуальність проблеми формування професійних компетентностей майбутніх фрахівців декоративноприкладного мистецтва засобами народного декоративно-прикладного мистецтва дає підставу до виділення таких протиріч:

1) між об'єктивною необхідністю збереження і розвитку декоративно-прикладного мистецтва як невід'ємною частиною самобутньої народної культури і орієнтацією у професійній підготовці майбутніх фрахівців декоративно-прикладного мистецтва здебільшого на інтернаціональні тенденції і західноєвропейську культуру;

2) між вивченістю питань формування професійних компетентностей студентів у педагогічній теорії і практиці та їх недостатньою розробленістю 3 підготовки фрахівців декоративно-прикладного мистецтва;

3) між можливостями народного декоративноприкладного мистецтва як засобом формування професійних компетентностей майбутніх фрахівців декоративно-прикладного мистецтва і відсутністю методичного забезпечення процесу їх реалізації [6, с. 165-174].

Якісної підготовки майбутніх фрахівців декоративно-прикладного мистецтва не може бути без створення методики навчання художнього ткацтва майбутніх фрахівців декоративно-прикладного мистецтва в закладах вищої освіти. Разом із тим постає питання щодо висвітлення сутності та структури поняття «компетентностей із мистецтва художнього ткацтва майбутніх фрахівців декоративно-прикладного мистецтва».

Основна проблема визначається створенням оптимально продуктивної методики навчання художньому ткацтву майбутніх фрахівців декоративно-прикладного мистецтва, що забезпечує високий рівень формування компетентностей із художнього ткацтва як складника профресійної компетентності майбутнього фрахівця декоративно-прикладного мистецтва. Загалом методика 
навчання художнього ткацтва передбачає фрормування сукупності компетентностей із художнього ткацтва у майбутніх фрахівців декоративно-прикладного мистецтва. Тому поняття «методика навчання художнього ткацтва» і «фрормування компетентностей із художнього ткацтва» ми розглядаємо як суміжні. Без сукупності фрахових компетентностей не можна досягнути професійної досконалості в оволодінні методикою.

У сучасному освітньому і соціокультурному просторі спостерігається величезний інтерес до відродження традицій художнього ткацтва. На сучасному етапі в просторі інтернет-технологій $€$ багато матеріалів із художнього ткацтва, які фррагментарно використовуються в освітньому просторі. Наявність навчальної літератури, різноманіття авторських програм по ручному ткацтву, вільний доступ в інтернеті до етнографрічних матеріалів дає додаткову можливість для створення унікальних сучасних проектів із застосуванням технологій [8].

Сучасні художники займаються пошуком нових оригінальних форм із застосуванням технологічно складних прийомів художнього переплетення ниток, фрактури і текстури художніх природних і штучних текстильних матеріалів. У цьому їм допомагає найдавніше ремесло, яке часом виявляє себе із несподіваного боку у вирішенні образу і формоутворення.

Створення педагогічних умов щодо збереження традицій декоративно-прикладного мистецтва і народних художніх промислів необхідне для того, щоб художній творчий досвід розкрився для студентів як джерело традиційної художньої спадщини.

Для вирішення питань забезпечення наочності у навчанні текстильному проектуванню необхідно створювати систематизовані матеріали у вигляді альбомів, навчальних посібників, методичних розробок за такою тематикою: «Композиційна побудова текстильного геометричного орнаменту», «Плетіння і ткацтво поясів», «Ручне ткацтво на рамі», «Ручне ткацтво », що розкриває можливості для найкращої реалізації ідей, закладених у компетенціях.

Вивчення студентами різних прийомів художнього ткацтва, практичне застосування вивчених технік у сучасному різноманітті текстильного проектування необхідні для підвищення виразності. Це стає можливим завдяки виділенню чітких основ художнього проектування, в якому застосовуються закономірності побудови геометричного орнаменту за допомогою комп'ютерних програм. Знання та навички, набуті на практичних заняттях із текстильним проектуванням, застосовуються в художньо-творчій, прикладній діяльності, у побуті, в дизайні костюма, дизайні інтер'єру.

3 огляду на різний інтерес студентів, рівень їхніх умінь, можна їх комплектувати по групах для розробки індивідуальних і колективних проектів.
Виконані навчальні практичні роботи обов'язково необхідно супроводжувати коментарями, організовувати поточні перегляди, а також відбирати найбільш вдалі проектні розробки для виставок [13].

Успіх творчої роботи залежить від захопленості студентів, хорошої організації занять із ними, забезпечення практичних занять необхідними інструментами, матеріалом для роботи. При плануванні навчальної роботи необхідно враховувати кількість студентів, годин, тематику завдань для кожного курсу залежно від напряму і форм навчання, їхню складність, методику проведення занять і організацію перегляду підсумкових робіт [4].

Досвід викладання показує, що на початковому етапі потрібно проводити знайомство студентів 3 матеріалами і теорією техніко-технологічних основ у переплетенні ниток. Далі необхідно вивчити закономірності побудови текстильного орнаменту за дидактичним принципом від простого до складного. Застосування технік у композиції різних видів виробів для інтер'єру та дизайну костюма має відбуватися поетапно, з огляду на прийнятий у декоративно-прикладному мистецтві поділ на різні види виробів, що стає важливою практикою, а й необхідне студентам для підвищення їхньої професійної підготовки.

У навчанні слід звертатися до традиційних виробів, які складають об'єкти предметно-матеріальної культури: одяг: пояси, сумки, декоративні елементи одягу, поясні вироби, головні убори, спідниці, сукні, блузи, пальто; площинні вироби: рушники, серветки, скатертини; покривала, накидки на крісло; декоративні настінні панно, портьєри, технології та дизайн авторської ляльки (при реконструкції народних костюмів) [7, с. 244-250].

Висновки. Основною проблемою профресійної підготовки студентів на художньо-графічних фракультетах $€$ ефрективне фрормування компетентностей студента у процесі навчання декоративноприкладному мистецтву. У більш вузькому контексті проблемою $є$ відсутність загальної методики навчання художньому ткацтву майбутніх фрахівців декоративно-прикладного мистецтва, яка забезпечить повноцінне формування компетентностей із мистецтва художнього ткацтва у майбутніх фрахівців із декоративно-прикладного мистецтва.

Загалом методика навчання художнього ткацтва передбачає формування сукупності компетентностей із художнього ткацтва у майбутніх фрахівців декоративно-прикладного мистецтва. Тому поняття «методика навчання художнього ткацтва» і «формування компетентностей із художнього ткацтва» ми розглядаємо як суміжні. Без сукупності фрахових компетентностей не можна досягнути професійної досконалості в оволодінні методикою [12, с. 43-46].

Надалі плануються теоретичні дослідження, які передуватимуть створенню методики навчання художнього ткацтва майбутніх фрахівців декоративноприкладного мистецтва в закладах вищої освіти. 


\section{БІБЛІОГРАФІЧНИЙ СПИСОК:}

1. Андрущенко В.П., Зязюн І.А., Кремень В.Г. Максименко С.Д., Ничкало Н.Г., Сисоєва С.О., Цехмістер Я.В., Чалий О.В. Неперервна професійна освіта: фрілософрія, педагогічні парадигми, прогноз : монографрія / за заг. наук. ред. В.Г. Кременя. Київ : Наукова думка, 2003. 853 с.

2. Балик Н.Р., Шмигер Н.П. Формування інфрормаційних та соціальних компетентностей студентів 3 метою їх професійної підготовки у педагогічному університеті. Науковий огляд : міжнародний науковий журнал. 2016, № 4. С. 71-79.

3. Бриткевич М.С. Инновационный педагогический опыт как фрактор профессионального совершенствования учителя в условиях системы повышения квалификации : автореф. дис. канд. пед. наук : 13.00.01. Белгород, 2018. 20 с.

4. Бучківська Г.В. Система професійної підготовки майбутніх вчителів початкових класів на засадах народного декоративно-ужиткового мистецтва : авторефр. дис. д-ра педагогічних наук: 13.00.04 / Тернопільський національний педагогічний університет імені Володимира Гнатюка. Тернопіль, 2019. 39 с.

5. Ващенко Л.С. Уміння вчитися - ключова компетентність студентської молоді сучасного інформаційного суспільства. Інформаційні технології і засоби навчання. 2014. № 5. С. 1-14.

6. Король А. Художньо-графрічна компетентність студентів загальноосвітніх навчальних закладів як педагогічна проблема. Збірник наукових праць. Вип. 2. Київ, 2016. С. 165-174.

7. Корнеева Е.Н., Кузнецов М.С. Создание интерактивного учебного пособия по текстиль- ному дизайну (в рамках программы этнодизайна). Перспективы науки-2015 : сб. докл. I Междунар. заоч. конкурса науч.-исследовательских работ, 12-26 окт. 2015 г. Т. 1 (Социально-гуманитарные науки). Казань : Рокета-Союз, 2015. С. 244-250.

8. Руденченко А.А. Теоретичні і методичні засади навчання етнодизайну студентів у вищих мистецьких навчальних закладах : автореф. дис. докт. пед. наук : 13.00.02. Київ, 2017. 42 с.

9. Оршанський Л.В. Концептуальні засади та модель художньо-трудової підготовки майбутніх вчителів трудового навчання. Сучасні інформаційні технології та інноваційні методики навчання у підготовці фрахівців: методологія, теорія, досвід, проблеми : зб. наук. праць. 2008. № 16. С. 421-426.

10. Оршанський Л.В. Художньо-трудова підготовка майбутніх вчителів трудового навчання : [монографрія]. Дрогобич : ШвидкоДрук, 2008. 278 с.

11. Свінцицька Н.М. Формування готовності майбутніх вчителів трудового навчання до роботи в гуртках декоративно-прикладної творчості: змістовий компонент підготовки. Педагогіка формування творчої особистості у вищій і загальноосвітній школах. 2016. № 50(103). C. 239-249.

12. Соколов М.В. Профрессиональная подготовка художника декоративного искусства на основе активизации проектной деятельности. Педагогическое образование в России. 2015. № 11. С. 43-46.

13. Сотська Г.І. Теоретичні і методичні засади формування естетичної культури майбутніх вчителів образотворчого мистецтва в педагогічних університетах : монографрія / за наук. ред. О.М. Отич. Київ : Ін-т обдарованої дитини, 2014. 382 с. 